\title{
Environment Identification of Plantation Plant Development for Competitive in Sukoharjo Districts, Indonesia
}

\author{
Irma Wardani* and Tria Rosana Dewi \\ Agribusiness Departement, Engineering, Sains and Agriculture Faculty, Islam Batik University \\ Surakarta, Jl. Agus Salim No.10, Surakarta 57147, Indonesia
}

\begin{abstract}
Developing the competitiveness of an area needs to identify the environment to determine the potential of the region. This study aimed to determine the environment that affects the development of plantation crops in Sukoharjo. Data analysis techniques used were Analytical Hierarki Process and Strength Weakness Opportunities Threats. The results showed the direction of the development of plantation crops was productivity. The priority plantation crops developed in Sukoharjo Regency were Sugar Cane (0.2929), Coconut (0.2017), Java Tobacco (0.1650), Medicinal Plants (0.12834), Cashew (0.1259), and Kapok (0.0085). Identification on the development of estate crops as follows internal factors such as i) strengths: available land, farmer institutions, social culture, availability of human resources,ii) weaknesses: low farmer education, lack of farmer coaching, expensive labor. While the external factors were i) opportunities: availability of seeds from the government, mechanization assistance for land, market demand, land expansion, the presence of sugarcane processing factories, biotechnology ii) threats: land use change, sugarcane farmers competition, pest and disease attacks, farmers moving.
\end{abstract}

Keywords: Crops, farmers competition, productivity

\section{Introduction}

Development of identical plantations with large industrial components and sources of state revenue to make plantation products for export. The selection of priority commodities to be developed can contribute to regional development. This research aimed to determine priority plantation crops to be developed in Sukoharjo districts, Indonesia. The data analysis technique used is the AHP (Analytical Hierarki Process) method [1].

The results indicate the direction of the development of plantation crops is productivity. The priority plantation crops developed in Sukoharjo districts are Cane (Saccharum officinarum L.) (0.2929), Coconut (Cocos nucifera L.) (0.2017), Tobaco (Nicotiana tabacum L.) (0.1650), Herb and Spices (0.1283), Cashew (Anacardium occidentale L.) (0.1259), Cotton (Ceiba pentandra L.) (0.0085). Identification on the development of estate crops as follows internal factors including i) strengths: available land, farmer the association, social culture, availability of human resources, ii) weaknesses: low farmer education, lack of farmer coaching, expensive labor. The external factors are i)

\footnotetext{
* Corresponding author: wardaniirma6@gmail.com
} 
opportunities: availability of seeds from the government, mechanization assistance for land, market demand, expansion of land, the presence of sugarcane processing factories ii) threats: land use change, sugarcane farmers competition, pest and disease attacks, farmers moving to other sectors.

\section{Material and methods}

\subsection{Material}

The study was conducted in Sukoharjo Regency, with primary data collection carried out by purposive sampling by interviews in the form of data and information or questionnaires.

\subsection{Method}

\subsubsection{Analytical hierarki process analysis}

The analysis used in this research was the AHP and SWOT analysis [2]. The procedure of the AHP was :

i. Arrange the hierarchy

Arrange the hierarchy of the problems faced, must first define the problem and determine the desired solution.

ii. Determine the priority

Table 1. Pairwise comparison matrix

\begin{tabular}{|l|l|l|l|l|}
\hline $\mathrm{G}$ & $\mathrm{A}_{1}$ & $\mathrm{~A}_{2}$ & $\mathrm{~A}_{3}$ & $\mathrm{~A}_{\mathrm{N}}$ \\
\hline $\mathrm{A}_{1}$ & $\mathrm{~A}_{11}$ & $\mathrm{~A}_{12}$ & $\mathrm{~A}_{13}$ & $\mathrm{~A}_{1 \mathrm{n}}$ \\
\hline $\mathrm{A}_{2}$ & $\mathrm{~A}_{21}$ & $\mathrm{~A}_{22}$ & $\mathrm{~A}_{23}$ & $\mathrm{~A}_{2 \mathrm{n}}$ \\
\hline$\ldots \ldots$ & $\ldots \ldots \ldots$ & $\ldots \ldots \ldots$ & $\ldots \ldots \ldots$ & $\ldots \ldots \ldots \ldots$ \\
\hline $\mathrm{A}_{\mathrm{n}}$ & $\mathrm{A}_{\mathrm{n} 1}$ & $\mathrm{~A}_{\mathrm{n} 2}$ & $\mathrm{~A}_{\mathrm{n} 3}$ & $\mathrm{~A}_{\mathrm{nn}}$ \\
\hline
\end{tabular}

$\mathrm{G}=$ Basic criteria of comparison

$\mathrm{Ai}, \mathrm{Aj}=$ Element below level is load

$\mathrm{Ij}=1,2,3, \ldots, \mathrm{n}$ is the index of the element in the level which are the same and are jointly related to the criteria $\mathrm{G}$.

Aij = the number given by comparing elements with the jth element, which is done with scale pairwise comparison.

iii. Synthesis

Add up the values of each column in the matrix and divide each value from the column by the total column in question, then add up the values of each row and divide by the number of elements to get the average value

Table 2. Criteria value matrix

\begin{tabular}{|l|l|l|l|c|c|}
\hline $\mathrm{G}$ & $\mathrm{A}_{1}$ & $\mathrm{~A}_{2}$ & $\mathrm{~A}_{\mathrm{n}}$ & Sum & Priority \\
\hline $\mathrm{A}_{1}$ & $\mathrm{~A}_{11} / \mathrm{a}$ & $\mathrm{A}_{12} / \mathrm{b}$ & $\mathrm{A}_{1 \mathrm{n}} / \mathrm{c}$ & $\mathrm{J}$ & $\mathrm{J} / \mathrm{n}$ \\
\hline $\mathrm{A}_{2}$ & $\mathrm{~A}_{21} / \mathrm{a}$ & $\mathrm{A}_{22} / \mathrm{b}$ & $\mathrm{A}_{2 \mathrm{n}} / \mathrm{c}$ & $\mathrm{K}$ & $\mathrm{K} / \mathrm{n}$ \\
\hline $\mathrm{A}_{\mathrm{n}}$ & $\mathrm{A}_{\mathrm{n} 1} / \mathrm{a}$ & $\mathrm{A}_{\mathrm{n} 2} / \mathrm{b}$ & $\mathrm{A}_{\mathrm{nn}} / \mathrm{c}$ & $\mathrm{L}$ & $\mathrm{L} / \mathrm{n}$ \\
\hline
\end{tabular}


iv. Measure consistency

The making decisions, it is important to know how good consistency

v. Multiply each value in the column by the relative priority of the elemen

Table 4. Row addition matrix

\begin{tabular}{|c|c|c|c|c|}
\hline $\mathrm{G}$ & $\mathrm{A}_{1}$ & $\mathrm{~A}_{2}$ & $\mathrm{~A}_{\mathrm{n}}$ & Sum line \\
\hline $\mathrm{A}_{1}$ & $(\mathrm{~J} / \mathrm{n}) \mathrm{A}_{11}$ & $(\mathrm{~J} / \mathrm{n}) \mathrm{A}_{12}$ & $(\mathrm{~J} / \mathrm{n}) \mathrm{A}_{1 \mathrm{n}}$ & $\mathrm{O}$ \\
\hline $\mathrm{A}_{2}$ & $(\mathrm{~K} / \mathrm{n}) \mathrm{A}_{21}$ & $(\mathrm{~K} / \mathrm{n}) \mathrm{A}_{22}$ & $(\mathrm{~K} / \mathrm{n}) \mathrm{A}_{2 \mathrm{n}}$ & $\mathrm{P}$ \\
\hline $\mathrm{A}_{\mathrm{n}}$ & $(\mathrm{M} / \mathrm{n}) \mathrm{A}_{\mathrm{n}}$ & $(\mathrm{M} / \mathrm{n}) \mathrm{A}_{\mathrm{n} 2}$ & $(\mathrm{~L} / \mathrm{n}) \mathrm{A}_{\mathrm{nn}}$ & $\mathrm{Q}$ \\
\hline
\end{tabular}

vi. Divide the results from the addition of rows with the relative elements concerned, then determine $\lambda$ max

Table 5. Value determination $\lambda$ maxs

\begin{tabular}{|c|c|c|c|c|}
\hline $\mathrm{G}$ & Priority & Sum line & Sum & $\Lambda \max$ \\
\hline $\mathrm{A}_{1}$ & $\mathrm{~J} / \mathrm{n}$ & $\mathrm{O}$ & $\mathrm{O}: \mathrm{J} / \mathrm{n}$ & \\
\hline $\mathrm{A}_{2}$ & $\mathrm{~K} / \mathrm{n}$ & $\mathrm{P}$ & $\mathrm{P}: \mathrm{K} / \mathrm{n}$ & \\
\hline $\mathrm{A}_{3}$ & $\mathrm{~L} / \mathrm{n}$ & $\mathrm{Q}$ & $\mathrm{Q}: \mathrm{L} / \mathrm{n}$ & \\
\hline$\Sigma$ & & & $\mathrm{S}$ & $\mathrm{S} / \mathrm{n}$ \\
\hline
\end{tabular}

vii. Consistency index

Consistency index is described in Equation (1):

$$
\begin{aligned}
& C I=\frac{\lambda_{\max }-n}{n-1} \\
& \mathrm{n} \quad=\text { Element }
\end{aligned}
$$

viii. Consistency ratio

Consistency ratio is described in Equation (2):

$$
C R=\frac{C I}{R I}
$$

$\mathrm{CR} \quad=$ Consistency Ratio

IR = Index Random Consistency

CI $=$ Consistency Index

The design of this study starts from observing data and information to agencies or institutions related to the research to determine the priority of estate crops commodities, then make a questionnaire, for AHP analysis. The results of AHP analysis in the form of 
priority commodities, then identified environmental factors that influence the development of plantation crops.

\subsubsection{Environment analysis}

Table 7. Environment identification

\begin{tabular}{|l|l|ll|}
\hline \multicolumn{3}{|c|}{ Environment identification } \\
\hline 1. & Strength : & 3. & Opportunities: \\
\hline 2. & Weakness : & 4. & Threat : \\
\hline
\end{tabular}

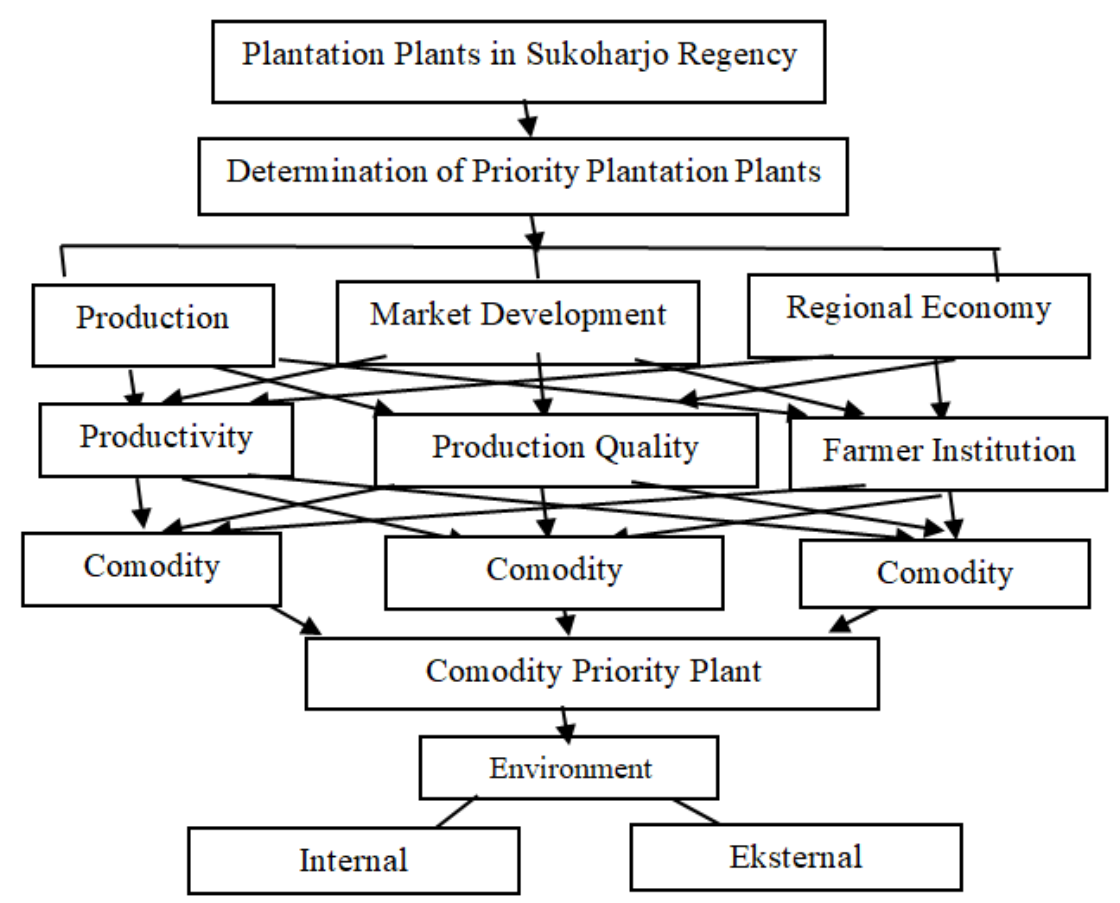

Fig 1. Research design

\section{Results and discussions}

The agricultural sector became one of the main saviors of the economy in Indonesia. It indirectly involves the role of the plantation subsector. The plantation sector holds an important role in the development of the economy in Indonesia [3].

The geographical, plantation district has an area of $466.66 \mathrm{~km}^{2}$ which consists of 12 districts. Sukoharjo district has ten commodities in the plantation sector. Plantation as an integral part of the agricultural sector is a sub sector that has an important and strategic role in national development [4]. 
Table 8. The results of production smallholder plantation

\begin{tabular}{|l|l|r|r|r|r|r|}
\hline \multirow{2}{*}{ No. } & \multicolumn{1}{|c|}{ Commodities } & \multicolumn{5}{c|}{ Productivity (t) } \\
\cline { 3 - 7 } & & $\mathbf{2 0 1 4}$ & $\mathbf{2 0 1 5}$ & $\mathbf{2 0 1 6}$ & $\mathbf{2 0 1 7}$ & $\mathbf{2 0 1 8}$ \\
\hline 1. & Coconut (Cocos nucifera L. $)$ & 580.72 & 587.98 & 589.53 & 589.98 & 580.74 \\
\hline 2. & Clove (Syzygium aromaticum L.) & 0.90 & 0.98 & 1.03 & 1.01 & 1.01 \\
\hline 3. & Kapok (Ceiba pentandra L.) & 68.48 & 70.91 & 71.33 & 70.98 & 71.01 \\
\hline 4. & $\begin{array}{l}\text { Cashew (Anacardium occidentale } \\
\text { L.) }\end{array}$ & 58.73 & 63.06 & 68.29 & 68.29 & 69.14 \\
\hline 5. & Cane (Saccharum officinarum L.) & 4212.23 & 4413.62 & 3852.06 & 2084.58 & 3582.28 \\
\hline 6. & $\begin{array}{l}\text { Candlenut (Aleurites moluccanus } \\
\text { L.) }\end{array}$ & 0.08 & 0.10 & 0.10 & 0.08 & 0.092 \\
\hline 7. & Tobaco (Nicotiana tabacum L.) & 2067 & 257.50 & 196.27 & 307.95 & 150.3 \\
\hline 8. & Herbs and spices & 0 & 0 & 1836.00 & 0 & 0 \\
\hline 9. & Sesame (Sesamum indicum L.) & 30.25 & 13.75 & 0 & 0 & 0 \\
\hline 10 & Catton (Ceiba pentandra L.) & 0 & 0 & 0 & 0 & 0 \\
\hline
\end{tabular}

Source: Agriculture and Fisheries Agency Sukoharjo District, 2019

Plantation commodities in Sukoharjo District are much effort by local farmers scattered in $12 \mathrm{sub}$ Districts in Sukoharjo District. The development of plantation commodities tended to increase every year, some commodities have not increased production for several years. Therefore, for the development of plantation commodities, need to determine priority commodities for Sukoharjo District, Indonesia.

The development of a priority commodity needs to determine the purpose so obvious for development of the commodity and to know the factors that influence in developing the priority commodity [5]. Analysis to determine the commodity using AHP then be identified internal and external factors. Determination of the purpose of the development of leading plantation commodities is the level of productivity, market development and improvement of the regional economy [6].

Table 9. Priority plantation

\begin{tabular}{|l|c|c|}
\hline \multicolumn{1}{|c|}{ Commodity } & Score priority & Number \\
\hline Cane (Saccharum) & 0.29297 & 1 \\
\hline Kapok (Ceiba pentandra) & 0.08588 & 6 \\
\hline Cashew (Anacardium occidentale) & 0.12597 & 5 \\
\hline Coconut (Cocos nucifera) & 0.20178 & 2 \\
\hline Tobaco (Nicotiana tabacum) & 0.16506 & 4 \\
\hline Herbs and spies & 0.12834 & 4 \\
\hline
\end{tabular}

Source : Primary data , 2019 
From Table 9, the sugarcane commodity was ranked 1, this shows the sugar cane commodity can be a superior commodity. Sugar cane is a plant that is widely cultivated to meet raw materials in more than 58 sugar factories in Indonesia. Cane plantation production has a high productivity compared to other plantation commodities. Cane is a plantation crop that has priority to be developed. Sugar cane plantation is located in Polokarto, Sukoharjo District, which has a land area of 680.23 ha.

Environmental conditions necessary for sugarcane cultivation include tropical or temperate climatic conditions with plentiful supply of water: approximately for more than 6 mo annually - either from rainfall or irrigation; with frost not favoring its growth and up to altitudes of $1600 \mathrm{~m}$. Sukoharjo Regency is located at an altitude of $125 \mathrm{~m} . \mathrm{a} . \mathrm{s} .1$ to 80 m.a.s.l. The highest place above sea level is the Subdistrict of Polokarto, which is 125 m.a.s.l., and the rainfall that occurs along. Geographical conditions support the development of sugarcane.

The first International Conference for Sustainable Plantation (The $1^{\text {st }}$ ICSP), 101 presenters were presented in the first ICSP, discussing sustainable development of many estate crops. The major estate crops and plantations presented in the first ICSP include cocoa, coconut, coffee, nutmeg, oil palm, rubber, pepper, sago palm, sugar cane, sugar palm, tea, and other miscellaneous plantation crops and research areas related to the crops [7].

Plantation-based industries have the ability to be the leading sect of economic growth, employment, and also encourage increased income distribution. One of the downstream plantation industries is the sugar industry [8].

Other important roles can also be seen from the perspective of food security, investment absorption, and the extent of linkages in the downstream industry, such as the food industry, beverage industry, refined sugar industry, pharmaceutical industry, paper, MSG, particle board, and bio-energy.

Sugar industry is also highly related to local resources, thus high value commodities can be developed for the empowerment of the people's economy. Therefore, the presence of the sugar industry can be an economic asset and at the same time an important social asset [9]. The study prospect of developing sugarcane needs to identify internal and external factors [10]. The identification results shown in Table 10.

Table 10. Identification of internal and external factors of cane plants

\begin{tabular}{|l|l|}
\hline Internal factors & External factors \\
\hline Strength & Opportunity \\
1. Available land & 1. Seed from the government \\
2. Association farmers & 2. Subsidy mechanization for the land \\
3. Social Culture & 3. Market demand \\
4. Available people & 4. Expansion land \\
Weakness & 5. Manufacturing sugar cane \\
1. Low education farmers & 6. Biotechnology \\
2. Lack of coaching for farmers & Threat \\
3. labor is expensive & 1. Transfer of land function \\
& 2. Competition of sugarcane farmers \\
& 3. Pests and diseases \\
& 4. Farmers move to other sectors \\
\hline
\end{tabular}

Source : Primary data , 2019 
Polokarto, Sukoharjo District, is one of the suppliers of raw materials for the Tasikmadu sugar factory in Karanganyar District thus it has a significant opportunity to be developed and supported by an increase in the community consuming sugar. Sugarcane is managed by local farmers in Polokarto, but the amount of costs to pay farmers is a weakness, and it is feared that farmers will also switch professions. Biotechnology plays an important role for the improvement of Sugarcane varieties. Biotechnological approaches for sugarcane improvement in the following areas such as (i) Cell and tissue culture for rapid propagation genetic transformation and molecular breeding, (ii) Introduction of novel genes into commercial cultivars, (iii) Molecular detection of sugarcane pathogens,(iv) Development of genetic maps using molecular marker technology, (v) Understanding the molecular basis of sucrose accumulation, (vi) Molecular testing of plants for clonal fidelity, (vii) Variety identification, and (viii) Molecular characterization of various traits [11].

Sugarcane productivity can be disturbed by pests and diseases [12]. The sugar productivity often experiences obstacles, one of which is insect pests. Losses caused by pests and diseases are quite high, around $10 \%$ decrease in sugar production. The results of the identification of internal and external factors are used as a reference in the strategy of developing sugarcane.

\section{Conclusion}

Sugarcane has the potential to be developed in Sukoharjo, Indonesia. Environmental factors are an important concern for developing sugarcane. The internal factors can also influence the development of sugarcane. Therefore, biotechnology as the application of technology is very important to be able to develop sugarcane varieties. Increasing the number of varieties, sugar cane plants can increase competitiveness in the market.

\section{References}

1. Brunelli, Matteo. Introduction to the Analytic Hierarchy Process. (2015).p.83

https://www.springer.com/gp/book/9783319125015

2. D.Oreski. TEM Journale 1,4:283-291(2012).

http://tem-

journal.com/documents/vol1no4/pdf/Strategy $\% 20$ development $\% 20$ by $\% 20$ using $\% 20 \mathrm{~S}$

WOT\%20-\%20AHP.pdf

3. W.S. Abir. Jurnal Ilmiah Universitas Batanghari Jambi. 16,1:134-141(2016). [in Bahasa Indonesia].

http://ji.unbari.ac.id/index.php/ilmiah/article/view/93/88

4. H. Rakhmad. Social Economic of Agriculture. 2,1:54-66(2013). https://jurnal.untan.ac.id/index.php/jsea/article/view/5119

5. F. Novitasari, R.V. Ayuningtyas, J. Regional and Rural Dev. Plan. 2,3:218227(2018).

https://journal.ipb.ac.id/index.php/p2wd/issue/view/2285 / or DOI: https://doi.org/10.29244/jp2wd.2018.2.3.218-227

6. F.R. David. Strategic Management: Concept and Case. Prentice Hall. (2010).p.290 https://www.google.com/url?sa=t\&rct=j\&q=\&esrc=s\&source=web\&cd=\&cad=rja\&ua

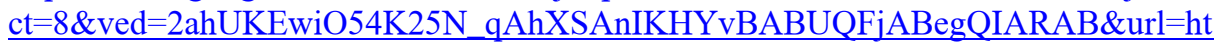
tp\%3A\%2F\%2Fperpustakaan.kasn.go.id\%2Findex.php\%3Fp\%3Dfstreampdf\%26fid\%3D28\%26bid\%3D327\&usg=AOvVaw0vXSkN9fXzvVyF3ciOLbGh

7. S. Sudarsono, A. Junaedi. IOP Conf. Series: Earth and Environmental Science. 418:011001(2020). 
https://www.google.com/url?sa=t\&rct=j\&q=\&esrc=s\&source=web\&cd=\&cad=rja\&ua ct=8\&ved=2ahUKEwjH-

YP15N_qAhVVbn0KHZ1CC14QFjAAegQIBRAB\&url=https\%3A\%2F\%2Fiopscien ce.iop.org\%2Farticle $\% 2$ F $10.1088 \% 2$ F 1755 -

1315\%2F418\%2F1\%2F011001\%2Fpdf\&usg=AOvVaw0K1Xfncwd6OKMv3WHmS $\underline{\mathrm{MNm}}$ or doi:10.1088/1755-1315/418/1/011001

8. Y.T.F. Marpaung, P. Hutagaol,W.H. Limbong, N. Kusnadi. Ind. J. Agric. Eco. 2,1:1-14(2011).

https://www.google.com/url?sa=t\&rct=j\&q=\&esrc=s\&source=web\&cd=\&cad=rja\&ua $\mathrm{ct}=8 \& v e d=2$ ahUKEwjtqMGi5d_qAhWEYysKHUbsDa0QFjAAegQIARAB\&url=http s\%3A\%2F\%2Fid.linkedin.com\%2Fin\%2Fyanto-togi-ferdinand-marpaung-sp-mmmsc-808b4ba\&usg=AOvVaw1jJPUwdclQq_SohxEuCe5I

9. S. Omwoma, M.N.T. Arowo, J. Lalah. Environ. Res. J. 8,3:293-330(2015). DOI:

https://www.google.com/url?sa=t\&rct=j\&q=\&esrc=s\&source=web\&cd=\&cad=rja\&ua $\underline{\mathrm{ct}=8 \& \mathrm{ved}=2 \mathrm{ahUKEwiLrYKC5d} \text { qAhVIU30KHZQxDSQQFjABegQIARAB\&url=htt }}$ ps\%3A\%2F\%2Fwww.researchgate.net $\% 2$ Fpublication $\% 2 F 272182537$ Environmenta 1_Impacts_of_Sugarcane_Production_Processing_and_Management_A_chemist_Pers pective\&usg=AOvVaw1amJHvGrVfFIY2tAdqO4HQ

10. E. Gurel. J. Int. Soc. Res. 10,51:994-1006(2017). http://sosyalarastirmalar.com/cilt10/sayi51_pdf/6iksisat_kamu_isletme/gurel_emet.pdf

11. A.K. Tiwari, Y.P. Bharti, S. Tripathi, N. Mishra, M. Lal, G.P. Rao, et al. Acta Phytopathol. Entomol. Hun. 45:235-249(2010). DOI: 10.1556/APhyt.45.2010.2.1 or https://www.google.com/url?sa $=$ t\&rct=j\&q $=\&$ esrc $=$ s\&source $=$ web \&cd $=\& c a d=$ rja $\& u a$ ct=8\&ved=2ahUKEwiD-

bWP5d_qAhXMAnIKHUwuBVwQFjAAegQIBBAB\&url=https\%3A\%2F\%2Fwww.r esearchgate.net $\% 2$ Fpublication\%2F235333195_Biotechnological_Approaches_for_I mproving_Sugarcane_Crop_with_Special_Reference_to_Disease_Resistance\&usg=A OvVaw3w1IuPPGaq6H0QGT6S1JoS

12. A.K. Srivastava, M.K. Rai. Biodiversitas Journal of Biological Diversity. 13,4:214227(2012).

https://smujo.id/biodiv/article/view/144 